\title{
Information Acquisition And Utilization As Determinants of Organizational Effectiveness: A Study Of Managers In Large Scale Manufacturing Industries In Nigeria.
}

\author{
Dr. S. O. Popoola \\ Department Of Library, \\ Archival And Information Studies, \\ University Of Ibadan, Ibadan, Nigeria
}

\begin{abstract}
This study examined information acquisition and utilization as determinants of organizational effectiveness of managers in large-scale manufacturing companies specializing in industrial and domestic products in Nigeria. The questionnaire was used for data collection from the $\mathbf{3 6 0}$ sampled managers out of which 332 responded and the copies of their questionnaire were found valid for analysis. The study found that the studied companies had moderate organizational effectiveness. Information acquisition, information sources and services' utilization had significant relationship with organizational effectiveness of the respondents. However, information acquisition, information sources and services' utilization of the managers had significantly determined organizational effectiveness of the manufacturing companies specializing in industrial and domestic products in Nigeria. It was therefore recommended that the management and board of directors of the companies should encourage their managers to acquire relevant information and use it to improve their organizational effectiveness. In addition, corporate library staff should provide effective information services to the managers so as to improve organizational effectiveness of their companies.
\end{abstract}

Keywords:- Information Acquisition, Information Utilization, Organizational Effectiveness, Managers, Nigeria.

\section{BIODATA}

Dr. S.O. Popoola is a Lecturer in the Department of Library, Archival and Information Studies, University of Ibadan, Ibadan, Nigeria. His research interests cover Information for Organizational Development, Archives and Records Management and Knowledge Management.

\section{INTRODUCTION}

Information which is defined as knowledge in communicable form, is recognized today as one of the essential resources like land, labour, capital, machines and energy necessary for achieving organizational effectiveness. Organizational effectiveness is the ability of an organization to fulfill its mission by achieving its objectives through a combination of sound management, strong governance and a continous rededication to assessing and achieving results. Managers in modern business organizations like manufacturing companies need information to provide creative and feasible solutions to strengthen the overall health and performance of their companies.

Information accessibility and utilization assist managers in manufacturing companies to better position their firms to meet current and future requirements by identifying and strengthening key functions such as planning, organizing, directing, decision making and controlling; and by developing, assessing and executing alternative structure options targeting at improving organizational effectiveness. Information availability and use enable managers in business 
organizations to address workload issues, lower volume of backlog, increase staff productivity, improve customer service and reduce costs of business operations by mapping core processes and carrying out detailed analysis to change, streamline, automate and or remove key activities in order to increase their organizational effectiveness. The improvement of organizational effectiveness is what every manager aims at in any manufacturing company. Managers in manufacturing firms may acquire and use relevant information devise mechanisms for production control standards to determine various levels of resource utilization and thereby to reduce costs of production of goods. Organizational effectiveness in business organization is associated with planning, decision making, staffing and controlling. (Buchele, 1962). In actual fact, developing competencies and competency-based personnel management approaches, focusing on the organization's missions, values and strategic objectives depends heavily on information acquisition, analysis and utilization. Information acquisition and use of managers for fostering organizational effectiveness in any business organization may be constrained by their level of information availability, accessibility, information literacy skills and cognitive ability. Information acquisition may be defined within the context of this study as gathering of knowledge in communicable form capable of improving organizational effectiveness of managers in manufacturing companies.

However, changes, events and trends take place in the business environment that continually send signals, messages and symbols which managers in organizations like manufacturing companies must detect, acquire, analyse and use to adapt to new conditions so as to improve their organizational effectiveness. The main reason why certain forms of organizations survive and thrive while others languish and perish in the business world is partly due to low perception of information, lack of gathering and use of relevant, accurate, complete, reliable and timely information by the managers for better business performance or organizational effectiveness.

Rosewell (1997) remarked that the company executive managers and directors need financial data, stock market information, information on mergers and acquisition of firms, business ownership, shareholders and government policies to formulate business strategic plans. Horton (1985) contended that organizations should regard information as a resource like energy and matter. Managers in organizations must see information as corporate asset and make concerted efforts to acquire, process and use it to improve their business success particularly organizational effectiveness.

Opeke (1984) stressed the ability of a manager in an organization to put himself/herself in such a position as to contact relevant information sources that are likely to be related to the operations and services provided by his/her organization and the manager's ability to select appropriate information sources to resolve a specific decision situation at a given material time are very important to their organizational success. Choo(1994) reported that the least frequently used information sources by the Chief Executives of Canadian telecommunications industry when acquiring information from their business environment were government officials, conferences, business trips, company library and electronic information services. Hayashi(2004) reiterated that the key to business survival in the current environment is to gather as much information as possible and utilize it effectively as possible. If managers should utilize information effectively, they must appropriately apply information to improve their managerial functions so as to stimulate organizational effectiveness. Information utilization in this study is operationalise as the suitable application of knowledge in communicable form capable of engendering organizational effectiveness of managers in manufacturing companies. Ezomo(2001) found that there existed a significant relationship between information flow and organizational effectiveness in a public service organization in Nigeria. Falola(2004) also 
reported that information acquisition and utilization capabilities significantly determined administrative effectiveness of employees in selected local government in Osun state in Nigeria. Okwuilagwe(1995) established that there was a significant relationship between the use of strategic information and organizational effectiveness of decision makers in publishing houses in Nigeria. Preble, Rau and Reichel (1988) expressed that lack of conscious systematic and formalized methods of obtaining relevant information for use has adverse effects on job operations of managers in organizations. It must be noted that if job operations of managers in business organizations are adversely affected through their unconscious systematic and formalized procedures for collecting relevant information for use, it may also lead to organizational ineffectiveness. Choo (1999) ascertained that the sophistication, scope and intensity of information acquisition and use of any organization has a lot to do with level of its success, buoyancy and business performance. Williams (2000) opined that managers in business organizations need economic information such as stock markets, inflation rates, foreign exchange rates interest rates, tax payments, trade balances, government budgets, wages and salaries, unemployment rates, debt management and investment opportunities to improve their organizational performance. Sawyer, Ebrahimi and Thibodeaux (2000) found that chief executives of medium scale enterprises preferred and used external sources of information than internal sources of information to improve their firms' business performance. Aiyepekun (1989) opined that every private sector organizations regularly invest huge sums of money to organize and update their information arsenals. They also know the consequences of using, or not using appropriate and timely information, or of having appropriately timed information used against them. Be that as it may, can one argue that information acquisition and utilization of managers in some large-scale manufacturing companies will determine their organizational effectiveness? More so, there is scanty of empirical studies in the field of Library and information science in Nigeria or elsewhere that linked information acquisition and use of managers to organizational effectiveness. This study is expected to add to the body of knowledge and raise consciousness of managers to the relevance of information gathering and use to organizational effectiveness with special reference to manufacturing companies. It is against this backdrop that the present study investigates information acquisition and utilization as determinants of organizational effectiveness of managers in some large-scale manufacturing companies in Nigeria.

\section{Objectives of the Study}

The following are the specific objectives of the study:

1. To ascertain types of information acquired by the respondents.

2. To find out the major information sources utilized by the respondents.

3. To ascertain the major information services utilized by the respondents.

4. To find out the barriers to information utilization of the respondents.

5. To determine the level of organizational effectiveness of the studied manufacturing companies.

6. To find out the degree of multiple relationship among information acquisition, information sources utilization, information services utilization and organizational effectiveness of the respondents.

7. To ascertain if information acquisition, information sources utilization and information services utilization will determine organizational effectiveness of the respondents.

8. To find out the relative contribution of information acquisition, information sources utilization and information services utilization of the respondents to the determination of organizational effectiveness of the companies. 


\section{Research Hypotheses}

The following hypotheses guided the conduct of this study and they were all tested at $\alpha=0.05$ level of significance:-

1. There is no significant multiple relationship among information acquisition, information sources utilization, information services utilization and organizational effectiveness of the respondents.

2. Information acquisition, information sources utilization, information services utilization will not significantly determine organizational effectiveness of the respondents.

\section{LITERATURE REVIEW}

Organization effectiveness is an ambiguous and highly subjective variable that depends on who is defining organizational effectiveness (Cameron \& Whetten, 1983). Multiple constituents will define the same organization's effectiveness differently (Connolly \& Devtsch,, 1992). Organizational effectiveness has been defined in the psychodynamic literature as the extent to which an organization optimizes task accomplishment (Miller \& Rice, 1967). Hirschorn (1989) remarked that organizations that are team based, high involvement, and post-modern, still require competent authority boundaries in order to be effective. Rieth and Biderman (2003) reported that there existed a significant relationship between organizational effectiveness and authority boundary among employees of outpatient physical therapy clinics in Tennessee, Georgia and Alabama in America. Miller (2004) noted that organizational effectiveness of firms can be measured from the employees' productivity perspective. Denison (1989) enumerated new product development, sales growth, market share, cashflow and return on assets as key indices for measuring organizational effectiveness in any business organization. Similarly, Steers (1975) listed fourteen criteria for measuring organizational effectiveness of firms which include adaptability - flexibility of firms, productivity, satisfaction, profitability, resource acquisition, absence of strain, control over environment, development, efficiency, employee retention, growth, integration, open communications, and survival. Mott(1972) observed that most criteria of organizational effectiveness fall into variables affecting organizational performance more easily applicable. They are output which is the quality and quantity of a good or service created, and the efficiency with which it is produced. Adaptability which is the long-term ability to cope with change technology, culture and behaviour. Flexibility which is the short-term ability to swift resources to cope with unexpected contingencies.

However, Robbins (1992) averred that power control is one of the most important factors that lead to organizational effectiveness. Peters and Waterman (1982) posited that effectiveness of an organization is also influenced by the organizational culture, which affects the way the managerial functions of planning, organizing, staffing, leading and controlling are carried out. According to Pfeffer and Salancik (1978) organizations survive to the extent that they are effective and they are effective to the extent that environmental information and resource dependencies are managed successfully. Organizational effectiveness for the purpose of this study is defined as the degree to which an organization like manufacturing company has met its stated goals and objectives and how well it performed in the process. The indicators used in measuring this include profitability, survival, growth, satisfaction, productivity among others. Daft (1998) submitted that in the internal process approach, effectiveness is measured as internal organizational health and efficiency. An effective organization has a smooth, well-oiled internal process. Employees are happy and satisfied. Departmental activities mesh with one another to ensure high productivity.

It is very important to stress at this juncture that information is an essential ingredient for assessing organizational effectiveness of any firm. Adebisi (2006) supported this assertion when he opined that the great majority of workers constantly use data, information and 
knowledge- each to varying degrees in their jobs. They create, manage, share, receive and/or manipulate information to improve their organizational effectiveness. Business information comes in general surveys, data, articles, books, references, Internet and internal records that managers require and use to guide their planning, operations, and the evaluation of their business activities in an organization. Such information may also acquire through friends, customers, associates, and vendors. Published sources of information of managers in business organizations may be daily newspapers, financial, trade and association magazines, databases, government statistics, directories, technical manuals, patents and standards, directories, journals, theses and dissertations, reports, company library, and much else. External information equally comes to the attention of managers in organizations in a variety of forms from printed materials to broadcast reports to online dissemination. Managers need to acquire and use both external and internal business information for the survival of their organization in the face of keen market competition. Okello-Obura et.al (2008) reported that managers in small and medium scale enterprises in Uganda did not consider radio broadcast, Internet/Email, television, conferences, libraries, telecentres, notice boards and politicians as reliable means of acquiring their needed information for use. Makenzie (2005) established that line managers in American-based corporations acquired their information needs through social networks. O'Connell and Zimmerman (1979) reported that managers in business firms in America acquired and utilized legal, economic, political, competitive, cultural and technological information to carry out their managerial functions. Fredenberger, Lipp and Watson (1997) studied the information requirements of managers who specialized in reviving failing business and they reported that financial, working capital, cost, expense, personnel, asset, and market analysis reports were either directly or indirectly used to improve cash flows while a company is in a financial crisis. Okwilagwe (2001) found that the appropriate utilization of internally and externally generated information had significant positive effects on the organizational effectiveness of publishing companies in Nigeria. Goodman (1993) found a positive correlation between management success and effective information needs assessment, gathering and use. Choo (1993) posited that managers need to use information not only for decision making and making sense of changes and developments in their external environment but also to generate new knowledge which can be applied to design new products and services, enhance existing offerings and improve organizational processes. deAlwis and Higgins (2001) reported that managers in Singaporean companies used information resources to prepare report, strategic plan and executive summary. The frequency of usage of information sources by managers in the business world may be due to information richness of a source available to him/her. Daft and Lengel (1986) reiterated that information media used in organizations offer different degrees of richness. Information richness may be viewed as the high quality information carrying capacity of a source or medium in bridging the gap in knowledge of a user on a random event. Popoola (2003) found that managers in oil companies in Nigeria most frequently used colleagues, subordinate staff, customers, government publications, and newspaper/magazines to acquire information and monitoring events occurring in their external business environment. Sawyerr, Ebrahimi and Thibodeauz (2000) investigated the executive environmental scanning, information source utilization and firm performance of small and medium-sized enterprises in Nigeria and found that environmental scanning practices did not appear to affect organizational performance as measured by profit margin and return on equity. Adegboye (2006) established that environmental scanning and information usage of managers in Osun State Community banks in Nigeria significantly correlated with business performance as measured by profit making of the banks. Information availability, acquisition and utilization may facilitate organizational effectiveness of firms in any financial or manufacturing company (Adewumi, 2006). White (1986) examined the relationship between managers functional roles and their information needs and uses in ten 
manufacturing firms in Britain. He found that there existed significant correlation between their information uses and functional roles. In addition, the major information resources used by the managers were the personal contacts which they considered as the best sources of intelligence on markets and competitors. Wilson (1985) opined that information as a stuff and processes serves people in organizations in the performance of their tasks, and the stuff and processes whereby it is obtained or acquired and used vary form person to person, from task to task, and from level of level in the organization.

\section{RESEARCH METHODOLOGY}

The descriptive research design of survey type was adopted for the study. The quota sampling technique was used to select 40 managers each from the 9 large-scale manufacturing companies specializing in the production of industrial and domestic products quoted on the Nigerian Stock Exchange as at 2008. making a total sample size of 360 managers. A selfdeveloped questionnaire called Information Acquisition, Utilization and Organizational Effectiveness (IAUOE) scale was used for data collection. The IAUOE scale was divided into four main sections: Section A deals with demographic information of the respondents such as name, gender, age, marital status, educational level, job tenure, and management cadre and department of work. Section B deals with information acquisition of the respondents, that is, types of information acquisition. It has 13 items and the response format are very highly acquired $=4$, High Acquired $=3$, Occasionally Acquired $=2$ and not Acquired $=1$. This sub-scale has a reliability coefficient of 0.68 using Cronbach Alpha Method. Section D deals with information utilization of the respondents, such as sources of information utilized, types of information services utilized, constraints to information utilization. The response format are very highly utilized $=4$, Highly Utilized $=3$, Occasionally Utilized $=2$ and Never Utilized $=1$. It has a reliability coefficient of 0.79 using Cronbach-Alpha method. Section D deals with the Organizational Effectiveness of the companies. It is a-10 point rating scale having 14 items. The total maximum score is 140 and total score obtained is converted to percentage score and the average percentage score of organizational effectiveness is obtained for each company. A score of 10-39 = low organizational effectiveness, 40-69 = moderate organizational effectiveness, and 70-100 equals high organizational effectiveness. It has a reliability coefficient of 0.84 using Cronbach-Alpha method. Nine hired research assistants who were postgraduate students in the Faculty of Social Sciences of the University of Ibadan, Ibadan, Nigeria administered the IAUOE scale on the 360 managers in the studied manufacturing companies out of which 332 responded and the copies of their questionnaire found valid for analysis resulting in 92.2 percent response rate. The data collection lasted for five months (April-August, 2008). The data collected at the headquarters of the company in Lagos was analysed using frequency tables, percentages, means and standard deviations as well as correlation and multiple regression analyses with the aid of computer software package for social sciences. The questionnaire administration and retrieval is presented in table 1.

Table 1: Questionnaire Administration and Retrieval

\begin{tabular}{|l|c|c|c|}
\hline Company & Number Administered & Number Retrieved & Response Rate (\%) \\
\hline Eric Dynamics PLC & 40 & 32 & 80 \\
\hline BOC Gases PLC & 40 & 25 & 62.5 \\
\hline Niyamco PLC & 40 & 20 & 50 \\
\hline Vono Products PLC & 40 & 40 & 100 \\
\hline Vitafoam Nigeria PLC & 40 & 35 & 87.5 \\
\hline Alumaco PLC & 40 & 40 & 100 \\
\hline First Aluminium Nigeria PLC & 40 & 40 & 100 \\
\hline Nigeria Enamel Ware Company, PLC & 40 & 40 & 100 \\
\hline Aluminium Extrusion Industry PLC & 40 & 40 & 100 \\
\hline Total & 360 & 332 & 92.2 \\
\hline
\end{tabular}




\section{RESULTS}

The gender distribution of the respondents revealed that 115 (34.6\%) were female managers while the rest $217(65.4 \%)$ were male managers. This means that male managers dominated the managerial positions in the studied companies. Of the 332 respondents, $265(79.8 \%)$ were married and $67(20.2 \%)$ were single. The ages of the respondents ranged between 25 and 53 years with mean $(x=39.8, S D=8.65)$ years. The highest educational distribution of the respondents showed that 107 (32.2\%) had Bachelor degree certificate, 142 (42.8\%) had postgraduate diploma certificate and $83(25 \%)$ had Master degree certificate. Their job tenure ranged between 5 and 28 years with mean $(x=18.6, S D=6.45)$ years. This implies that the studied companies were blessed with highly experienced people who occupied their managerial positions. Out of the 332 respondents, 186 (56\%) were junior managers, 92 $(27.7 \%)$ were senior managers and 54 (16.3) were executive managers.

Nevertheless, Table 1 shows the mean and standard deviation scores of types of information acquisition by the respondents.

Table 1: Mean and Standard Deviation Scores of Types of Information Acquired by the Respondents

\begin{tabular}{|l|c|c|}
\hline Types of Information & $\mathrm{X}$ & $\mathrm{SD}$ \\
\hline Market demand/supply & 3.99 & 0.182 \\
\hline Sources of raw materials & 3.99 & 0.191 \\
\hline Price data & 3.97 & 0.174 \\
\hline State of technology & 3.96 & 0.172 \\
\hline Market profit volume/sales size & 3.94 & 0.184 \\
\hline Exchange rates & 3.94 & 0.182 \\
\hline Interest rates & 3.92 & 0.168 \\
\hline Tax laws & 3.91 & 0.152 \\
\hline Household income/expenditures & 3.84 & 0.163 \\
\hline Labour matters & 3.82 & 0.149 \\
\hline Environmental management & 2.68 & 0.032 \\
\hline Crime rate & 2.63 & 0.044 \\
\hline Community relations & 1.23 & 0.088 \\
\hline
\end{tabular}

The major types of information acquired by the respondents were market demand and supply $(x=3.99, S D=0.182)$, sources of raw materials $(x=3.99, S D=0.191)$, price data $(x=3.97, S D=$ $0.174)$, state of technology $(x=3.96, S D=0.172)$, market profit volume and sales size $(x=3.94$, $\mathrm{SD}=0.184)$, exchange rates $(\mathrm{x}=3.94, \mathrm{SD}=0.182)$, interest rates $(\mathrm{x}=3.92, \mathrm{SD}=0.168$ and tax laws $(\mathrm{x}=3.91, \mathrm{SD}=0.152)$. Information on community relations was never acquired by the respondents. Nevertheless, table 2 presents mean and standard deviation scores of information sources utilization of the respondents. The customers $(x=3.99, S D=0.122)$, Company files $(\mathrm{x}=3.98, \mathrm{SD}=0.121)$, reports $(\mathrm{x}=3.98, \mathrm{SD}=0.122)$, Internet/CD-ROM databases $(\mathrm{x}=3.95, \mathrm{SD}=0.124)$, newspapers $/$ magazines $(\mathrm{x}=3.94, \mathrm{SD}=0.120)$, company library $(\mathrm{x}=3.92$, $\mathrm{SD}=0.123)$, journals $(\mathrm{x}=3.90, \mathrm{SD}=0.125)$, and textbooks $(\mathrm{x}=3.90, \mathrm{SD}=0.124)$. 
Table 2: Mean and Standard Deviation Scores of Information Sources Utilization of the Respondents

\begin{tabular}{|l|c|c|}
\hline Information Sources & $\mathrm{X}$ & $\mathrm{SD}$ \\
\hline Customers & 3.99 & 0.122 \\
\hline Company files & 3.98 & 0.121 \\
\hline Reports & 3.98 & 0.122 \\
\hline Internet/CD-ROM databases & 3.95 & 0.124 \\
\hline Newspapers/magazines & 3.94 & 0.120 \\
\hline Company library & 3.92 & 0.123 \\
\hline Journals & 3.90 & 0.125 \\
\hline Textbooks & 3.90 & 0.124 \\
\hline Patents/standards & 3.89 & 0.120 \\
\hline Trade literature & 3.89 & 0.122 \\
\hline Government documents & 3.88 & 0.119 \\
\hline Radio/television & 3.85 & 0.117 \\
\hline Professional associates & 3.84 & 0.118 \\
\hline Colleagues & 3.84 & 0.118 \\
\hline Subordinate staff & 3.81 & 0.114 \\
\hline Indexes and abstracts & 3.76 & 0.110 \\
\hline Theses/dissertations & 1.22 & 0.019 \\
\hline
\end{tabular}

were the major sources of information sources utilized by the respondents. They never utilized theses and dissertations $(\mathrm{x}=1.22, \mathrm{SD}=0.019)$ when sourcing their needed information.

However, table 3 presents the mean and standard deviation scores of information services utilization of the respondents. The major information services utilized by the respondents were online information $(\mathrm{x}=3.96, \mathrm{SD}=0.119)$, data processing $(\mathrm{x}=3.94, \mathrm{SD}=0.117)$, current awareness $(\mathrm{x}=3.92, \mathrm{SD}=0.116)$, facsimile $(\mathrm{x}=3.92, \mathrm{SD}=0.115)$, electronic data interchange $(\mathrm{x}=3.91, \mathrm{SD}=0.116)$, photocopying $(\mathrm{x}=3.90, \mathrm{SD}=0.114)$, and documents delivery $(\mathrm{x}=3.90$, SD = 0.113). Teleconferencing and information broking were never utilized by the respondents. All the respondents indicated that

Table 3: Mean and Standard Deviation Scores of Information Services Utilization of the Respondents

\begin{tabular}{|l|c|c|}
\hline Information Services & $\mathrm{X}$ & $\mathrm{SD}$ \\
\hline Online information service & 3.96 & 0.119 \\
\hline Data processing & 3.94 & 0.117 \\
\hline Current awareness & 3.92 & 0.116 \\
\hline Facsimile & 3.92 & 0.115 \\
\hline Electronic data interchange & 3.91 & 0.116 \\
\hline Photocopying & 3.90 & 0.114 \\
\hline Documents delivery & 3.90 & 0.113 \\
\hline Telephone/telex & 2.95 & 0.109 \\
\hline Referral & 2.93 & 0.106 \\
\hline Indexing and abstracting & 2.92 & 0.104 \\
\hline Bindery/lamination & 2.86 & 0.102 \\
\hline Teleconferencing & 1.15 & 0.012 \\
\hline Information broking & 1.14 & 0.011 \\
\hline
\end{tabular}


Poor information literacy skills and uncooperative attitude of the company library personnel, long time taken to acquire the needed information were the real barriers to their information utilization when carrying out their job functions.

Table 4: Mean and Standard Deviation scores of organizational Effectiveness of the Respondents

\begin{tabular}{lll} 
Variables & X & SD \\
\hline Adaptability-flexibility & 9.85 & 2.46 \\
Productivity & 6.74 & 1.41 \\
Satisfaction (Staff) & 9.62 & 2.32 \\
Profitability & 6.49 & 1.38 \\
Resource acquisition & 7.42 & 1.52 \\
Absence of strain & 6.50 & 1.30 \\
Control of environment & 6.44 & 1.42 \\
Development & 6.38 & 1.28 \\
Efficiency & 6.44 & 1.22 \\
Employee retention & 9.74 & 2.24 \\
Growth & 6.32 & 1.18 \\
Integration & 6.40 & 1.16 \\
Open communication & 8.56 & 2.44 \\
Survival & 6.08 & 1.34 \\
$-\cdot--.-19$
\end{tabular}

The respondents were asked to rate their organizational effectiveness based on indices/variables provided on Table 4 and according to survey of the available literatures on a 10-point scale, the score between 1-3 means low organizational effectiveness, the score between 4-6 means moderate organizational effectiveness while the score between 7-10 means high organizational effectiveness. One can therefore, deduce that the studied organizations were highly effectiveness in their business operations in respect of adaptability/flexibility, employees' retention, staff satisfaction, open communication and resource acquisition. It is very surprising to find that they were moderately effective in critical areas of their business performance like profitability, productivity, control of environment, development, growth survival and absence of strain.

Nonetheless, the mean and standard deviation scores of organizational effectiveness of the companies is presented in Table 4. 
Table 5: Mean and Standard Deviation Scores of Organizational Effectiveness of the Studied Companies

\begin{tabular}{|l|c|c|c|c|}
\hline Companies & $\mathrm{n}$ & $\mathrm{x}$ & $\mathrm{SD}$ & Remark \\
\hline Eric Dynamics PLC & 32 & 55.82 & 5.68 & $\mathrm{MOE}$ \\
\hline BOC Gases PLC & 25 & 48.64 & 6.42 & $\mathrm{MOE}$ \\
\hline Niyamco PLC & 20 & 62.22 & 7.20 & $\mathrm{MOE}$ \\
\hline Vono Products PLC & 40 & 59.78 & 5.56 & $\mathrm{MOE}$ \\
\hline Vitafoam Nigeria PLC & 35 & 72.26 & 8.50 & $\mathrm{HOE}$ \\
\hline Alumaco PLC & 40 & 81.44 & 6.72 & HOE \\
\hline First Aluminium Nigeria PLC & 40 & 74.40 & 7.34 & HOE \\
\hline $\begin{array}{l}\text { Nigeria Enamel Ware Company, } \\
\text { PLC }\end{array}$ & 40 & 68.88 & 5.40 & MOE \\
\hline $\begin{array}{l}\text { Aluminium Extrusion Industry PLC } \\
\text { Industry PLC }\end{array}$ & 40 & 88.12 & 8.21 & HOE \\
\hline Overall & 332 & 67.95 & 6.82 & MOE \\
\hline
\end{tabular}

NB:- LOE = Low Organizational Effectiveness, MOE = Moderate Organization Effectiveness and $\mathrm{HOE}=$ High Organizational Effectiveness. The mean scores of organizational effectiveness of the studied companies ranged between $(\mathrm{x}=48.64, \mathrm{SD}=6.42)$ and $(\mathrm{X}=88.12, \mathrm{SD}=8.21)$. The overall mean scores of their organizational effectiveness is $(x=67.95, S D=6.82)$. One can therefore deduce that the studied companies had moderate organizational effectiveness.

However, the result of data analysis in table 5 showed that organizational effectiveness had a significant positive relationship with: information acquisition $(r=0.5262, \mathrm{P}<0.05)$; information sources utilization $(\mathrm{r}=0.6185, \mathrm{p}<0.05)$ and information services utilization $(\mathrm{r}=0.5882$, $\mathrm{p}<0.05$ ) of the respondents. Table 5 presents the results of data analysis on test of significant relationship between independent variables and organizational effectiveness of the respondents.

Table 5: Summary of Tests of Significant Relationship Between Organizational Effectiveness and Independent Variables

\begin{tabular}{|l|c|c|c|c|}
\hline Variables & $\mathrm{X}$ & $\mathrm{SD}$ & $\mathrm{OE}(\mathrm{r})$ & Sig. P \\
\hline Information acquisition (IA) & 18.28 & 4.25 & 0.5262 & 0.019 \\
\hline Information sources utilization(ISU 1$)$ & 20.45 & 5.16 & 0.1682 & 0.036 \\
\hline Information services utilization & 21.98 & 5.22 & 0.5882 & 0.028 \\
\hline Organizational effectiveness & 67.95 & 6.82 & 1.000 & - \\
\hline
\end{tabular}

Moreso, information acquisition, information source utilization and information services utilization had significant multiple relationship with the organizational effectiveness of the respondents $(\mathrm{R}=0.6532, \mathrm{P}<0.05)$. Nonetheless, the results of regression analysis of independent variables, that is information acquisition (IA), Information Sources Utilization $\left(I S U_{1}\right)$ and Information Services utilization $\left(\mathrm{ISU}_{2}\right)$ on the dependable variable which is organizational effectiveness (OE) as shown in table 6 revealed that information acquisition, information sources utilization and information services utilization of the respondents when taken together significantly determined organizational effectiveness of their companies. $(\mathrm{F}=$ $16.18, \mathrm{df}=3 ; 328, \mathrm{p}<0.05$ ) 
Table 6: Summary of Regression Analysis of Independent Variables on Organizational Effectiveness.

\begin{tabular}{|l|c|c|c|c|c|}
\hline Source of variation & Df & SS & Ms & F & Sig. P \\
\hline Due to regression & 3 & 5826 & 1942 & & \\
\cline { 1 - 4 } Due to error & 328 & 39360 & 120 & \multirow{2}{*}{16.18} & 0.008 \\
\hline Total & 331 & 45186 & 2062 & & \\
\hline
\end{tabular}

Multiple R(adjusted) $=0.6532$

Multiple R Squared (adjusted) $=0.4268$

Standard Error of Estimate (SEE) $=10.9545$

The value of $\mathrm{R}$ Squared which is 0.4268 implies that the linear combination of information acquisition, information sources utilization and information services utilization of the respondents accounted for 42.68 percent of the total variability in organizational effectiveness of their companies. The results of further data analysis as presented in Table 7 showed that information sources utilization was the most potent variable $(B=0.3214, \mathrm{df}=328, \mathrm{t}=8.37$, $\mathrm{P}<0.05$ ) apart from information services utilization $(\mathrm{B}=0.2218, \mathrm{df}=328, \mathrm{t}=4.86, \mathrm{P}<0.05)$.

Table 7: Relative contribution of Independent Variables to the Determination of Organizational Effectiveness of the Companies

\begin{tabular}{|c|c|c|c|c|c|}
\hline Variable & $\mathrm{B}$ & SE(B) & $\mathrm{t}$ & Betain & Sig. P \\
\hline Constant & 1.8241 & 0.4288 & 4.25 & - & 0.018 \\
\hline Information Acquisition (IA) & 0.1128 & 0.0221 & 5.10 & 0.2811 & 0.031 \\
\hline Information Sources Utilization (ISU I & 0.3214 & 0.0384 & 8.37 & 0.4322 & 0.022 \\
\hline Information Services Utilization $\left(\mathrm{ISU}_{2}\right)$ & 0.2218 & 0.0456 & 4.86 & 0.3241 & 0.033 \\
\hline
\end{tabular}

and information acquisition $(\mathrm{B}=0.1128, \mathrm{df}=328, \mathrm{t}=5.10, \mathrm{P}<0.05)$ in determining organizational effectiveness of the studied companies. This is predicated on the fact that information acquisition (Betain $=0.2811$ ) contributed 28.11 percent, information sources utilization (Betain $=0.4322$ ) contribute 43.22 percent and information services utilization of the respondents (Betain $=0.3241$ ) contributed 32.41 percent to the determination of organizational effectiveness of their companies. The estimated regression model that shows the determination of organizational effectiveness of the studied companies from the stand point of information acquisition, information sources and services utilization of managers therein can be mathematically expressed thus $\mathrm{OE}=1.8241+0.1128 \mathrm{IA}+0.3214 \mathrm{ISU}_{1}+0.2218$ $\mathrm{ISU}_{2}$

\section{DISCUSSION OF FINDINGS}

Information is now a precious resource that managers in business organizations like manufacturing companies, are continuously seeking for, acquire and utilize for their organizational development. Any manufacturing companies that fail to acquire, manage and utilize high quality information in the production of value-added goods will find it difficult to compete favourably in the global market. The reason being that consumers are rational in nature and they will demand for the products with high quality and moderate price.

However, this study found that the major types of information acquired by the respondents are market demand/supply, sources of raw materials, price data, state of technology, market profit volume/sales size, exchange rates, interest rates; and tax laws. The information acquisition of the respondents covers economic, technological and legal matters relating to their managerial functions. This findings is in line with that of early study of O'Connell and Zimmerman (1979) who reported that managers in business firms in America acquired and used legal, economic, 
political, competitive, cultural and technological information to carry out their managerial functions. In the same vein, Correria and Wilson (1997) found that managers in the Portuguese chemical industry acquired information regarding social, cultural, demographic, economic and political trends as well as market competition for managing their business uncertainty.

This study also established that the major information sources utilized by managers in the chemicals and paints companies in Nigeria include customers, company files, reports, Internet/CD-ROM databases, Newspapers/Magazines, company library, journals, and textbook among others. It is very surprising to find that the managers in the studied companies never utilized these and dissertations when performing their managerial functions. Theses and dissertations contain original and reliable information that will be useful for these managers to improve their organizational effectiveness. Popoola (2004) supported this finding when he reported that female managers in oil companies in Nigeria utilized company records, online databases, colleagues technical reports, newspapers/magazines, government publications, patents/standards, textbooks, and journals among others in their decision making process. Oladele (2008) reiterated that information utilization by workers particularly managers at both tactical and strategic levels of management is very vital in improving organizational effectiveness in both manufacturing and financial companies. Popoola (2003) studied environmental scanning for strategic advantage of managers in oil companies in Nigeria and found that colleagues, subordinate staff, customers, government publications and newspapers/magazines were the most frequently used sources of information by them. It must be noted that external sources of business information like government publications, newspapers and magazines, trade associations, trade literature and suppliers can be invaluable in helping managers in manufacturing companies determined appropriate courses of action and plan for the future. Daniells (1993) observed that companies that do rely exclusively on internal information sources run the risk of: remaining uninformed about important trends in the larger industry-including new products/services and competitor moves-until it is too late to respond effectively; and receiving skewed information from employees whose goals and opinions may not tally with the best interests of the companies. Managers in business organizations prefer to access and use human rather than documentary sources of information. Sawyer, Ebrahimi and Thibodeaux (2000) and Elenkov (1997) confirmed this assertion when they stressed that internal sources should not be neglected as they are frequently a rich and valuable source of information to managers particularly for planning, decision making and controlling. Makenzie (2005) found that line managers in American-based corporations acquired their information needs by building social networks. Kobrin et al (1980) reported that information sources used by large United State of America international firms to assess their foreign social and political environments were banks, regional managers, headquarters personnel, subordinates, colleagues in other firms, known and trusted people, as well as personal observations during frequent trips to foreign companies. It must be pointed out at this juncture that managers in manufacturing companies may use information sources that are considered relevant to their needs in order to enhance their organizational effectiveness.

However, this study found that managers in the studied companies very highly utilized online information services, data processing, electronic data interchange, photocopying, and documents delivery service. Contrarily, Maxwell (2001) submitted most business managers in the developing world failed to make use of the available electronic information service for better decision making. It is noteworthy that managers in the studied companies made use of Internet for e-mail, information acquisition and marketing of their products. In their study of large United Kingdom companies, Lesters and Waters (1989) found that managers made considerable use of online formation services. Indeed, mangers in manufacturing companies in the developing countries particular Nigeria have realized the potentials of using information 
and communication technologies to improve their business performance. Benzur (2005) reported that Western European companies used information and communication technologies such as telephone/telex, Internet, CD-ROM databases searching for competitive intelligence. Owen, Wilson and Abell (1995) averred that an increasing number of companies are now using information technology to support their information gathering and dissemination. This study also revealed that organizational effectiveness had significant correlations with information acquisition, information sources utilization and information services utilization of managers in large-scale manufacturing companies specializing in the production of industrial and domestic products in Nigeria. Okwilagwe (1995) corroborated this present finding when he reported that there existed a significant relationship between the use of strategic information and organizational effectiveness of decision makers in publishing houses in Nigeria. Williams (2000) reiterated that managers in business organizations acquired economic and market information to enhance their organizational performance. Oladunni (2008) opined that managers in manufacturing companies should acquire and use information to improve their organizational effectiveness. Malhotra (2000) averred that managers must endeavour to acquire and use information and knowledge to improve their electronic business performance. In actual fact, organizational effectiveness of industrial organizations depend to a great extent on the ability of their workforce particularly managers to acquire, use and disseminate high quality information. Mainsail Associates (2004) noted that organizational effectiveness reflects the internal functioning of an enterprise: the commitment to goals, objectives and ethical standards, the efficiencies of practices and processes and the perfect flow of work and information. The point being stressed here is that information is a critical factor input to foster organizational effectiveness in a business enterprise like manufacturing companies producing industrial and domestic products. Sawyer, Ebrahimi and Thibodeaux (2000) found that information sources utilization of chief executives of small and medium scale manufacturing companies in Nigeria affected their company performance as measured by profit margin and return on equity. Information is one of the corporate assets that modern organizations needs to achieve high turnover rate and profitability.

More so, this study found that information acquisition, information sources and services utilization simultaneously and independently had significantly determined organizational effectiveness of managers in manufacturing companies producing industrial and domestic products in Nigeria. And that a linear combination of information acquisition, information sources utilization and information services utilization of the managers accounted for 42.68 percent of the total variability in organizational effectiveness of the studied companies. In addition, information sources utilization of the managers had greatest relative contribution, next to it is the information services utilization of the managers and follow by information acquisition to the determination of organizational effectiveness of the studied companies.

\section{CONCLUSION AND RECOMMENDATIONS}

The information needs of managers in industrial organizations are diverse in nature and they are available within their business environment such as legal, economic, geographical, educational, political, social, technological and cultural. As information needs of managers are varied, they are contained in several sources with peculiar characteristics. Managers in manufacturing companies rely on and acquire their much needed information from numerous sources of information depending on the nature of the task to be performed. Most often times, their information acquisition and use are directed at improving their organizational business performance. Managers occupy a central position in manufacturing companies and their major work activities revolve around human resources management, budgeting, social networkings, communications, administration, information searching, information sharing, acquisition, and 
utilization with sole aim of improve their organizational effectiveness. However, one of the basic findings of this study is that information acquisition, information sources utilization and information services utilization of managers in the studied companies have significant relationship with their organizational effectiveness. Moreover, information acquisition, information sources utilization and information services utilization of managers significantly determined their organizational effectiveness. It is therefore recommended that the management and Board of Directors of the chemicals and paints companies in Nigeria should encourage their managers to acquire and use information to improve their organizational effectiveness. Also, the corporate libraries must endeavour to acquire relevant information resources and provide effective information services to meet the need of managers in the studied comapnies.

\section{References}

Adebisi, M.O. (2006) Role of Information Management and Information Use in Business Performance of Manufacturing Firms. Journal of Organizational Development, vol. 18, No. 2, pp. 140 - 151.

Adegboye, O.A. (2006) Environmental Scanning as a Correlate of Business Performance of Community Banks in Nigeria. PhD Thesis, University of Ibadan, 172p.

Adewumi, A.A. (2006) Information Needs, Utilization and Organizational Performance. Information Management Research, vol. 8, No. 2, pp. 55 - 68.

Aiyepeku, W.O. (1989) Information Priorities for Organizational Effectiveness. A Paper presented at the National Workshop on Information Dissemination and Crisis Management in Organizations. Department of Adult Education, University of Ibadan, 14 -17th July, 1989, pp. 1 - 24.

Benzur, D. (1995) Environmental Scanning: How Developed is Information Acquisition in Western European Countries. Information Research, vol. 11, No. 1, pp. 1 - 18.

Buchele, R.B. (1962) How to Evaluate a Firm. California Management Review, Fall, pp. 5 - 16.

Cameron, K.S. and Whetten, D.A. (1983) Organizational Effectiveness: A Comparison of Multiple Models. NewYork: Academic Press.

Choo, C.E. (1994) Perception and use of Information Sources in Environmental Scanning. Library and Information Science Research, vol. 16, No. 1, pp. $23-40$.

Choo, W.C. (1999) Closing the Cognitive Gaps: How People Process Information. London: Financial Times Mastering Information Management Series, 22 ${ }^{\text {nd }}$ March, pp. 1 - 13.

Connonlly, T. Contlon, E.J.; and Deutsch, S.J. (1992) Orgnizational Effectiveness: A Multiple - Consistency Approach. In Shafritz, J.M. and Ott, J.S. (eds) Classics of Organizational Theory (3 $3^{\text {rd }}$ ed.) Pacific Grove, CA: Brooks/Cole Publishing

Correria, Z. and Wilson, T.D. (1997) Scanning the Business Environment for Information: A Grounded Theory Approach. Information Research vol. 2, No. 4, pp. $1-12$.

Daft, R.L. (1998) Organizational Theory and Design, $6^{\text {th }}$ edition. Cincinnati: South - Western College Publishing.

Daft, R.L. and Lengel, R.H. (1986) Organizational Information Requirements, Media Richness and Structural Design. Management Science, vol. 32, No. 5, pp. 554 - 571.

Daniells, L.M. (1993) Business Information Sources. Berkley; University of California Press.

deAlwis, S.M. and Higgins, S.E. (2001) Information as a Tool for Management Decision-making. A case study of Singapore. Information Research, vol. 7, No. 1, pp. 1 - 34.

Denison, D.R. (1989) Corporate culture and Organizational Effectiveness. New York: John Wiley \& Sons.

Elenkov, D.S. (1997) Strategic Uncertainty and Environmental Scanning: The Case for Institutional Influences on Scanning Behaviour. Strategic Management Journal, vol. 18, No. 1, pp. 287 - 302.

Ezomo, A.I. (2001) Information flow and Organizational Effectiveness: A case study of Oyo State Primary Education Board. Unpublished M.ED Dissertation, University of Ibadan, Ibadan, 72p.

Falola, P.O. (2004) Information Acquisition and Utilization Capability as Determinants of Employees' Administrative Effectiveness in selected Local Government Offices in Osun State, Nigeria. Unpublished M.ED Dissertation, University of Ibadan, Ibadan, 110p. 
Fredenberger, W.B.; Lipp, A. and Watson, H.J. (1997) Information Requirements of Turnaround Managers at the Beginning of Engagements. Journal of Management Information Systems, Vol. 13, No. 4, pp. 167 - 192.

Goodman, S.K. (1993) Information for Management Decision Making. Management Research Quarterly, vol. 27, No. 4, pp. 1- 12.

Hayashi, H. (2004) High-Speed Information Utilization Technologies adopted by Interstage ShunSaku Data Manager. FUJITSU Science and Technology Journal, vol. 40, No. 1, pp. 110 - 116.

Hirschorn, L. (1998) Reworking Authority: Leading and following in the Post-Modern Organization. Cambridge, MA: MIT Press.

Horton, J.F.W. (1982) Needed: A new Doctrine for Information Resources Management. In J.F. Horton and Marchand, D. (ed.) Information Management in Public Administration. Airlington: Information Resources Press, pp. $45-57$.

Kobrin, S.J.; Basek, J.; Blank, S. and Lapalombara, J. (1980) The Assessment of Non-economic Environments by American Firms. Journal of International Business Studies, vol. 11, No. 1, pp. 32 - 47.

Lester, R. and Waters, J. (1989) Environmental Scanning and Business Strategy. London, England: British Library, Research and Development Department, 148p.

Mainsail Associates Inc. (2004) A Systems Model for Organizational Effectives. Technical Report, No. 15, pp. 1 20.

Makenzie, M.L. (2005) Managers look to the Social Network to seek Information. Information Research, vol. 10, No. 2, pp. $1-16$.

Malthotra, Y. (2000) Knowledge Management for Electronic Business Performance: Advancing Information Strategy to "Internet Time". Information Strategy: The Executives Journal, vol. 16, No. 4, pp. 5 - 16.

Maxwell, N.A. (2001) The Relevance of Electronic Services in the Business Management of Developing Countries. Information Management and Technology, vol. 12, No. 1, pp. $14-25$.

Miller, E.J. and Rice, A.K. (1967) Systems of Organization. London: Tavistock.

Miller, H. (2004) Quantifying and Fostering Organizational Effectiveness. US: Herman Miller Inc.

Mott, P.E. (1972) The Characteristics of Effective Organizations. NewYork: Harper \& Row, pp. 17 - 20.

O'Connell, J.J. and Zimmerman, J.W. (1979) Scanning the International Environment. California Management Review, vol. 22, No. 2, pp. 15 - 23.

Okello-Obura, C.; Minishi - Majanja, M.K.; Cloete, L. and Ikoja-Odongo, J.R. (2008) Sources of Business Information and Means of Access Used by SMEs in Uganda: The Case of Northern Uganda. LIBRES: Library and Information Science Research Electronic Journal, vol. 18, No. 1, pp. 1 - 28.

Okwilagwe, O.A. (1995) Information Input as a Factor in Organizational Effectiveness of the Publishing Industry in Nigeria. Unpublished PhD. Thesis, University of Ibadan, Ibadan, Nigeria, 202p.

Okwilagwe, O.A. (2001) Effects of Utilization of Internally and Externally generated Information on the Organizational Effectiveness of the Publishing Industry in Nigeria. Nigerian Journal of Applied Psychology, vol. 6, No. 2, pp. $153-167$.

Oladele, S.A. (2008) Management use of Information in Industrial Organizations in Developing Countries. Business Management Review, vol. 8, No. 2, pp. 55 - 67.

Oladunni, A.A. (2008) The Relationship of Information Needs, Utilization and Business Performance of Small and Medium-Sized Enterprises in Nigeria. Information Management Research, vol. 20, No. 3, pp. 25 - 42.

Opeke, R.O. (1984) Information Consciousness as a Factor in Organizational Decision Making: The Case of Ogun State Ministry of Education. PhD Thesis, University of Ibadan, Ibadan, Nigeria, 124p.

Owens, I.; Wilson, T.D. and ABell, A. (1995) Information and Business Perforamnce: A Study of Information Systems and Services in High-Performing Companies. Information Research, vol. 1, No. 2, pp. 1 - 10.

Pfeffer, J. and Salancik, G.R. (1978) The External Control of Orgnaizations: A Resource Dependence Perspective. NewYork: NY: Harper \& Row, 300p.

Popoola, S.O. (2003) Environmental Scanning for Strategic Advantage of Managers in Oil Companies in Nigeria. Nigerian Libraries, vol. 37, No. 1, pp. 42 - 56. 
Popoola, S.O. and Haliso, Y. (2004) Information Utilization in Decision making among Female Managers in Oil Companies in Nigeria. Nigerian Journal of Applied Psychology, vol. 8, No. 2, pp. 145 - 163.

Preble, J.F.; Rau, P.A. and Reichel. A. (1988) The Environmental Scannign Practices of US Multinationals in the late 1980s. Management International Review, vol. 28, No. 4, pp. 4 - 14.

Rieth, T.L. and Biderman, M. (2003) The Relationship between Organizational Effectiveness and Authority Boundary. Paper presented at the $18^{\text {th }}$ Annual Society for Industrial and Organizational Psychology Conference, Orlando, FL. Pp. 1 - 19.

Robbins, S. (1992) Organization Theory. New York: Prentice Hall, Englewood cliffs, NJ.

Rosewell, T. (1997) Managing Information: Discover Company Information. Managing Information, vol. 4, No. 1, pp. $27-30$.

Sawyer, O.0.; Ebrahimi, B.P.; and Thibodeaux, M.S. (2000) Executive Environmental Scanning, Information Sources Utilization, and Firm Performance: The Case of Nigeria. Journal of Applied Management Studies, vol. 9, No. 1 , pp. $95-115$.

Steers, R.M. (1975) Problems in the Measurement of Organizational Effectiveness. Administrative Science Quarterly, December, pp. 546 - 551.

White, D.A. (1986) Information Use and Needs in Organizations: Organizational Factors in Information Behaviour. International Journal of Information Management, Vol. 6, No. 3, pp. 157 - 170.

Williams, C. (2000) Management. Cincinnati, Ohio: South-Western College Publishing.

Wilson, T.D. (1985) Information Management. The Electronic Library, vol. 3, No. 1, pp. 61 - 66. 